Саша Д. Кнежевић

Универзитет у Источном Сарајеву

Филозофски факултет Пале

Катедра за србистику

sasa.knezevic@ffuis.edu.ba

https://doi.org/10.18485/ai_gozik.2019.ch7

821.163.41.09:398

\title{
И ДЕБЕЛОГ МЕСА ОВНУЈСКОГА - ФУНКЦИЈА ТОЦИВА И ПЕЦИВА У ПЈЕВАЧКОМ ОПУСУ ТЕШАНА ПОДРУГОВИЋА
}

У српским епским народним пјесмама сцене гозбе везују се, између осталих функција, и за припреме јунака за бој. Најмилији Вуков пјевач Тешан Подруговић овим је сценама дао посебан тон, али и значај за шта је најзначајнији примјер пјесма „Марко Краљевић и Муса Кесеџија“, јер се траженом храном и пићем он повраћа на овај свијет чиме трпеза постаје веома битан фактор у чину преласка са једног на други свијет.

Кључне ријечи: трпеза, вино, ракија, хљеб, бој, снага, прелазак.

Осим што је Вуку Караџићу био омиљени пјевач, уистину и стога што своје пјесме није пјевао него казивао, Тешан Подруговић је са 22 пјесме и најзаступљенији рапсод у Караџићевим класичним збиркама. Подруговић је, дакле, био пјевач испјеваних пјесама, друготворац опјеваних јунака, преправљач и поправљач туђих стихотворенија, а опет јединствен и непоновљив. У поетичком коду који потире оригиналност и не познаје иновативност успио је створити сопствени израз заснован на три постулата, размијеваюу, осјећағу и 
мишлену које Караџић (1986: 394-395) истиче као доминанте његовог опуса: „Његова је свака песма била добра, јер је он (особито како није певао, неко само казивао) песме разумевао и осећао, и мислио је, шта говори“. Вук нас овим опажањем упућује на неминовно промишљање о томе како се Подруговић издваја од других пјевача као истински стваралац, јер три наречена постулата и чине суштину стваралачког чина.

С обзиром на то да се српска јуначка епика заснива на формулативним исказима свака врста оригиналности почиње и завршава на импровизацију унутар кодификованих схематских образаца. У суштини се овај образац огледа у његовом опјевавању хране и пића, при чему је неопходно редослијед преокренути у смјеру пића и хране. Од свих Подруговићевих пјесама вино се не помиње једино у пјесми „Марко Краљевић и кћи краља Арапскога“ што је и логично с обзиром на тематику пјесме и ситуационо позиционирање испијања вина у његовим стихотворенијима. Оно није присутно само у пјесмама о Марку Краљевићу, него се среће и у другим пјесмама. Примарно пиће његових јунака, који припадају старијим и средњим, дакле, херојским временима, представља вино које „је у индоевропским и оријенталским религијама (са изузетком, углавном, само ислама) имало велики углед и играло важну улогу у култу“ (Чајкановић 1973: 113). Прије свега вино се послужује у знак гостопримства као у пјесми „Женидба Душанова“:

Када дође бијелу Леђану, лијепо га краљу дочекао; вино пије неђељицу дана; ${ }^{1}$

1 Сви примјери из пјесама наведени су према Српске народне nјесме књ. 2, Београд: Просвета - Нолит, 1988. 
Нуђење храном и пићем основе су гостопримства које као обичај има веома дубоке коријене (в. Чајкановић 1973: 63-77), а које Чајкановић на истом мјесту повезује са исконским вјеровањем у теофанију. У истој пјесми Тодор везир ће тек након седам дана изрећи прави разлог слова предузећа, процијенивши да је провео довољно времена као неочекивани или незвани гост. Други незвани гост у овој пјесми, Милош Воиновић, неће тако лако утолити своју жеђ и то на најприроднијем мјесту за точење и испијање вина:

Ид’ одатле, црни Бугарине!

Да с' донијо бугарску копању,

Ако бих ти и усуо вина;

За те нису чаше позлаћене!

Механа је у земљи татинској, па је отуда претпостављено да је и механџија Латин и за њега не вриједи Србима карактеристичан однос према госту, али Подруговић ову ситуацију и користи за иницијалну изградњу Милошевог лика кроз трагикомичне ситуације које доводи до савршенства у пјесмама о Марку Краљевићу:

Погледа га Милош попријеко,

Удари га руком уз образе:

Колико га лако ударио,

Три му зуба у грло сасуо.

Моли му се млади механџија:

Не удри ме више, Бугарине!

Биће тебе вина изобила,

Ако цару неће ни достати.

Гротескне сцене нису ријеткост у Подруговићевим пјесмама (в. Кнежевић 2018: 47-57) и оне се најчешће 
повезују са хумором као репрезентативном особином његовог пјевања (Недић 1990: 33-34; Кољевић 1998: в. Зуковић 2006: 67-79). Ипак, Тешан Подруговић је пјевач изразитог осјећања за мјеру и стога такве сцене ситуационо везује за механу или гору, а за дом или двор везује друкчије призоре прикладне датој атмосфери. Свака сцена у двору природно одише сваколиким богатством и раскоши. Хајдучка иницијација Грујичина, којег отац и стриц продају распусној Џафербеговици јер више немају вина, ни дувана, започиње за трпезом:

И донесе господску вечеру.

Сједе Грујо вечер' вечерати.

Сагрешењу Находа Симеуна, којега је на зло навело то што га је вино преварило, у истоименој пјесми такође претходи сједање за богату трпезу:

Сједе њега за совру готову, Донесоше вино и ракију И лијепу сваку ђаконију. Сједи Симо, пије рујно вино.

У сљепачкој варијанти ове пјесме коју је Вук Караџић објавио под именом Опет Наход Симеун нема мјеста за ову сцену, као ни за цијелу епизоду о Симеуновом манастирском одрастању у којем га старац не даје дојиљама:

Већ га рани у свом намастиру,

Рани њега медом и шећером.

Ово је типичан примјер како Подруговић стару пјесму прилагођава свом пјевачком сензибилитету 
чиме је, према Светозару Матићу (1958: 647-648) „песник од хагиографије, од светачког житија, направио помало јуначку песму“. Матић није једини који Тешана Подруговића именује пјесником, јер он то уистину и јесте, ако ни због чега другог онда због тога што нам је подарио нама знаног Краљевића Марка.

„Како ми замишљамо појаву Марка Краљевића? Велики епски јунак језди друмом. Огрнуо је ћурак од курјака, на главу навукао капу од курјака. С једне стране седла објесио је тулумину вина, а с друге стране тешку топузину. Када се заустави крај пута и пободе копље у ледину, он пије мрко вино теђеном од дванаест ока - пола пије пола Шариу даје. Тако ми отприлике замишљамо нашег епског јунака. Све наведене појединости о спољашњем изгледу Марка Краљевића налазе се, међутим, само у песмама Тешана Подруговића. Ни у једној ранијој.“ (Недић 1990: 29)

Несумњиво је епски јунак старији од Подруговићевог пјевања, али је лик до своје идеалне мјере узрастао у његовом пјевању, гдје је постао свемоћни чудовишни јунак (в. Гете 1972: 170). Један од основних атрибута тог лика, споменут и у претходном цитату јесте испијање вина. Подруговићев Марко вино испија у разнородним приликама, нпр. са Љутицом Богданом у знак принудног измирења:

Пак сједоше пити рујно вино, Мезете га грозним виноградом;

уз поздрав који долази након што се „вина накитише“:

С Богом остај, Љутица Богдане! Да с’ у здрављу опет састанемо И црвена вина напијемо! 
У Подруговићевим пјесмама сцене гозбе су у потпуности функционалне и с правом се доводе у везу и са његовим изузетним физичким изгледом, у којем можемо пронаћи и аутобиографске елементе (Недић 1990: 31), али и јасне слојеве старијег постања „Марково херојско једење и још и више пијење преко мјере, може да се посматра у оквиру негативне али и позитивне карактеризације, будући да је та његова склоност посљедично произашла из Марковог ФИЗИЧКОГ ИЗГЛЕДА, исполинске и џиновске снаге, а самим тим и из потреба“ (Брђанин 2003: 100). Није Марко једини Подруговићев јунак оријашке величине и снаге. Такав је и његов Симеун:

Кад је била чеду годиница,

Колик' друго од три годинице!

Кад је било од три годинице,

Колик’ друго од седам година!

А кад било о седам година,

Колик' друго од дванаест љета!

Кад је било од дванаест љета,

Колик’ друго од двадест година!

Физичка величина и снага ће изазвати завист осталих ђака и постати мотив за његово лутање у потрази за трагичним усудом који ће се оваплотити у краљичиној постељи, а да ће уистину краљичина софра бити мјесто на коме обоје губе главу, она због његове љепоте, а он због вина.

Марко за трпезу сједа и са својом мајком у пјесми „Женидба Краљевића Марка“ „Сједе Марко за вечеру с мајком“, при чему она као фундаментални аргумент за женидбу очитује: 
О мој синко, Краљевићу Марко!

Већ је твоја остарјела мајка, Не може ти приправљат' вечере, А не може служит' мрка вина.

У истој пјесми Марка сједају за софру и у дјевојачком дому:

Краљу Марка на бијелу кулу,

За готову софру засједоше,

Па стадоше мрко пити вино.

Ово је непобитни доказ да вино код Тешана Подруговића има примат над храном, за шта проналазимо потврду у пјесми „Марко Краљевић и Вуча Џенерал“:

Донесе им вина и ракије

И лијепе сваке ђаконије,

што и није чудо кад се зна колико и на који начин Подруговићев Марко у њему ужива:

А пред њиме стоји тулум вина;

Не пије га чим се пије вино, Већ леђеном од дванаест ока, Пола пије пола коњу даје.

Када Бранко Брђанин (2003: 101) констатује: „Маркова тулумина вина почесто је саставни дио јунакове ратничке опреме, као нека алатка која ће да тешку тоnузину држи у равнотежи“, он прије свега мисли на Подруговићевог јунака, јер чак и у пјесми „Марко Краљевић и Филип Маџарин“, коју неријетко након аргументације 
Светозара Матића ${ }^{2}$ сматрају Подруговићевом, у опремању Шарца умјесто уобичајене сцене имамо:

Објеси му тешку топузину,

И гадаре с обадвије стране;

Марков афинитет према овој врсти тоцива познат је и самом цару који у антологијској завршној сцени пјесме „Марко Краљевић познаје очину сабљу“ свог посинка који га крвавих суза из очију доћера до дувара умирује са стотину дуката и ријечима „Иди Марко напиј ми се вина“. То нас упућује на један веома важан слој његовог епског карактера, јер „прекомерност у пићу има сасвим другачију генеалогију у склопу карактеризације епских јунака. Она, с једне стране, упућује на генерацију гиганата демијурга, делатних у време кад је камен био мек, чији су наследници епски јунаци, прекодирани у нижи, реалистичнији регистар“ (Делић 2018: 56). Подруговићеви јунаци су живи људи, симболи снаге и побједе над смрћу, па је сасвим природно што свог јунака нераскидиво везује за вино, јер „Чокот и вино су символ живота и спасења, принцип горнега света; кад дође нов, срећан век (који је имао да инаугурише Месија), онда ће, у првом реду, горе капати слатким вином“ "Чајкановић : 113).

Заправо у Подруговићевом корпусу једино у пјесми „Марко Краљевић и Ђемо Брђанин“ храна има предност пред вином. Цијели заплет је базиран на ријечима старог калуђера:

\section{Вала тебе, Краљевићу Марко! \\ Свега имаш у бијелу двору, \\ Још да имаш рибе од Орида!}

2 Више о овоме у: Светозар Матић, Значене геограбских детать ународном епу. 
Премда је на Марковој славској трпези било „Свему доста пива и јестива" пјевач проналази непосредни повод за Марков необични одлазак од куће који не подразумијева клишеизирано опремање што за посљедицу има његово заробљавање. У помоћ му прискаче крчмарица која трује његовог противника тако што му служи:

Рујна вина од седам година,
Меће у њег' биље свакојако.

У истој пјесми народ моли Ђема да не погубљује Марка пред њиховим градом ријечима:
Ботом брате, Ђемо Брђанине!
Ту нам немој објесити Марка,
Не ће родит' вино ни шеница,
Ево тебе три товара блага.

Александар Лома (2002: 103) повезаност Марковог лика са гњевним древним божанствима, а прије свега са богом грома Перуном потврђује и кроз његову сличност са Иљом Муромецом којег посредством трофункционалне идеологије ${ }^{3}$ са старим божанством доводе у везу теоретичари нове компаративне митологије.

3 Овај термин француски компаратиста Жорж Думезил појашњава: „Прву функцију чинила би власт, свештена, државна и правна; другу телесна снага и борбена вештина; трећу обиље и плодност. На друштвеном плану, овим трима функцијама би одговарала раслојеност на три сталежа, свештеничко-краљевски, војнички и сељачки, било да је она код појединих индоевропских народа постојала реално, или само као идеолошки постулат, одн. поетски идеал“ (према Лома 2002: 16), што по свему одговара епској карактеризацији Подруговићевом Краљевића Марка. 
„Тај суд може бити занимљив и за просуђивање епског лика Марка Краљевића, јер је већ уочена Маркова сродност са појединим богатирима руских билина, посебно Иљом Муромцем и Свјатогором, која не само да сведочи о постојању појединих епских мотива заједничких источним и јужним Словенима и према томе наслеђеним из прасловенске давнине, већ очитује њихово доследно везивање за херојски лик окарактерисан довољно јасним дистинктивним цртама, што упућује на закључак да се двојица богатира на једној и Марко на другој страни своде на један исти, праисторијски тип епског јунака, много старији од својих историјских конкретизација.“

За ово је најбољи примјер пјесма „Марко Краљевић и Муса Кесеџија“ у којој сцена гозбе поприма сасвим друкчију и нову функцију. Када повампиреног Марка хоџа Ћупријлић доведе пред ияара честитога његово питање и Марков одговор на најбољи начин исказују његово стање:

\section{Јеси л’ ђегод у животу, Марко? \\ Јесам, царе, али у рђаву.}

Марко се, према Ван Генепу (2005: XIX) у датом тренутку налази у трећој фази обреда прелаза коју карактеришу обреди пријема, односно прикључења новој-старој заједници живих. За такво што му је неопходна трпеза и то не било каква, него тражи:

Намјести ме ђегођ у механу, Примакни ми вина и ракије, И дебела меса овнујскога, И бешкота љеба бијелога; Да посједим неколико дана, 
Казаћу ти, кад сам за мејдана.

Јасна је симболика хране којом се Марко повраћа, али је занимљиво да се иста храна налази на Арапиновом уцјењивачком списку у пјесми „Марко Краљевић и Арапин“:
И на Стамбол он наметну намет:
Све на ноћцу по јалову овцу
И фуруну љеба бијелога,
Један чабар жежене ракије,
По два чабра црвенога вина.

То је дакле јуначка храна у српској традицији директно повезана и са култом мртвих уз јасну одредницу да се „у вину налази божанска, животворна снага“ (1973: 115), а исто тако Чајкановић подсјећа да се људи једењем обредне жртвене хране дивинизирају, па не чуди што на тај начин Марко стиче неприродну снагу којом ће исциједити двије капи из суве дреновине. Уопштено ова врста хране код Срба асоцира на обреде везане за мртве и подушја: „Припремљена храна (кољиво, хлеб, јела и посластице) и пиће (вода, црвено вино) изнети на гроб, најпре се издвајају и намењују покојнику“ (Јовановић 2002: 110). Њоме се, дакле, не кријепи само тијело, него првенствено душа која „Према веровањима нашег народа, она може бити у костима само док је човек жив, в. нпр. Вук, Посл., 1597: Запекла му се душа у костима. Кад се за кога хоће да каже да је стар врло, па опет неће да умре; упор. и Вук, Пјесме, 2, 74, 79, итд.: ...Јеси ли ми, брате, уживоту? .. 'Јесам, брате, али у рђаву: Убила ме рђа од тавнице, Једва носим у костима душу.““(Чајкановић : 109) 
Дакле, из тавнице се вратила душа, а тијело Марко је повратио причесном храном и пићем, самим тијелом и крвљу Божијим потврђујући Бахтинову (1978: 298) тезу да једење и пијење представљају побједу над свијетом. Није то једини случај да у Подруговићевим пјесмама онога ко се повраћа са оног свијета оживљавају на овај начин, наиме, када полумртви слуга Милутин на крвавом коњу ступи пред царицу Милицу да заврши трагични извјештај који су започели гаврани он моли своју госпу:

\section{Скин' ме госпо са коња витеза, Умиј мене студеном водицом, И залиј ме црвенијем вином; Тешке су ме ране освојиле.}

Животворност вина у овом случају не треба да дјелује на дуге стазе као у пјесми „Марко Краљевић и Муса Кесеџија“ јер је Милутину неопходно тек толико снаге да доврши рапорт с оне стране. Уосталом, он је јунак косовског циклуса који живи за јуначку смрт, а Краљевић Марко, поготово Марко Тешана Подруговића, оживљава да би убио „од себе бољега“, онај који никада „не показује ни превише жара да изгуби главу - њега ни најмање не привлачи могућност велике трагичке гесте и смрти“ (Кољевић 1998: 184). Њега је цар вратио из тамнице, са онога свијета, да погуби тросрцог Мусу Кесеџију и поврати хармонију која је подједнако нарушена Мусиним зулумом, колико и његовим изостанком. Између чудесног повратка и (не)херојске побједе над змајевитим јунаком, уврштена је епизода изванредне гозбе која је омогућила обоје.

Занимљиво да у овој пјесми постоји још један помен хране и то у сцени сусрета у качаничком кланцу 
гдје Муса Марку приговара како га је мајка „Одранила медом и шећером“, скоро дословно понављајући раније цитирани стих из „Находа Симеуна“ о исхрани господске дјеце, а који, према Светозару Кољевићу (1998: 194), „долази са трпезе беговских породица босанских Муслимана из Подруговићевих времена“, чиме се потврђује раније исказани став да је Подруговићева иновативност унутар задатог клишеа у највећој мјери заснована на вјештом инкорпорирању аутобиографских и њему блиских података у старе пјесничке оквире. Понекад се то јединство базира управо на опозицији, јер „Марко је заправо служио Турцима, а певач ове песме, омађијани хајдучки бусијаш и устаник Тешан Подруговић, тукао се са њима успешно где год је стигао“ (Зуковић 1995: 53).

Отуда је и богата трпеза, вјероватно, самом Подруговићу била често недосањани сан, па о њој пјева с љубављу и поштовањем као онај који нешто исконски жели. Испијање вина, без обзира да ли га пије Марко Краљевић „леђеном од дванаест ока“ или други јунаци на начин како се вино иначе пије, јесте у функцији пјесме и формирања епског лика. Његова божанска димензија припомаже понајприје разумијевању дубљих слојева на којима почива епски Краљевић Марко, онај и онакав каквог га нам је својим пјесничким генијем поначинио Тешан Подруговић.

\section{ЛИТЕРАТУРА}

Бахтин (1978): Bahtin, M. Stvaralaštvo Fransoa Rablea. Beograd: Nolit, 1978.

Брђанин (2003): Брђанин, Б. Марко Краљевић и српска драма. Српско Сарајево: Завод за уџбенике и наставна средства, 2003.

Ван Генеп (2005): Van Genep, A. Obredi prelaza. Beograd: SKZ, 2005. 
Гете (1982): Goethe, J. W. „Srpske narodne pesme“. Ka poetici narodnog pesništva, Beograd: Prosveta, 1982. 168-172.

Делић (2018): Делић, Л. „Карневалско устројство света, контекст, жанр: Опет то, али друкчије“. Научни састанак слависта у Вукове дане, 48/2. Београд: МСЦ, 2018. 51-62. Зуковић (1995): Зуковић, Љ. Историјски Краљь Марко и епски Краљевић Марко. Бања Лука: Нови глас, 1995.

Зуковић (2006): Зуковић, Љ. „Хумор у песмама Тешана Подруговића“. У духовном завичају, Источно Сарајево: Завод за уџбенике и наставна средства, 2006. 67-79.

Јовановић (2002): Јовановић, Б. Српска книга мртвих, Нови Сад: Прометеј, 2002.

Караџић (1986а): Караџић, В. С. Српске народне пјесме, кю. 2. Београд: Просвета, 1986.

Караџић (1986б): Караџић, В. С. Српске народне пјесме, къ. 4. Београд: Просвета, 1986.

Кнежевић (2018): Кнежевић, С. У тавници суние огријало. Београд: Филип Вишњић, 2018.

Кољевић (1998): Кољевић, С. Постаюе епа. Нови Сад: САНУ - огранак у НС, 1998.

Лома (2002): Лома, А. Пракосово. Београд: САНУ, 2002.

Матић (1934): Матић, С. „Значење географских детаља у народном епу“. Прилози проучавағу народне поезије, I/1. Београд, 1934. 12-15.

Матић (1958): Матић С. „Поговор“. Српске народне пјесме 2. Београд: Просвета, 1958.

Недић (1990): Недић В. Вукови певачи. Београд: Рад, 1990. Чајкановић (1973): Чајкановић В. Мит и религија код Срба. Београд: СКЗ, 1973. 
Saša D. Knežević

\section{DIE FUNKTION VON ESSEN UND TRINKEN IN DEN LIEDERN VON TEŠAN PODRUGOVIĆ}

In serbischen Volksliedern der Festivalszene sind sie unter anderem an die Vorbereitungen für den Kampf der Helden gebunden. Beloved Vukov Sänger Tešan Podrugović das ist die Szene einen speziellen Ton gab, und die Bedeutung das, was ist das wichtigste Beispiel für einen Song Musa Kesedžija, weil die erforderlichen Speisen und Getränke auf Erbrochenem in diese Welt, die Tabelle einen sehr wichtigen Faktor in der Tat wird auf einem bewegten eine andere Welt.

Schlüsselwörter: Tisch, Wein, Brandy, Brot, Schlacht, Kraft, Passage. 